\title{
Impacts of tracked vehicles on sediment from a desert soil
}

\author{
EREK H. FUCHS, M. KARL WOOD, TIM L. JONES, AND BRENT RACHER
}

Authors are former Research Assistant (currently Water Resource Master, Office of State Engineer, 133 Wyatt Dr. Suite 3, Las Cruces, N.M. 88005); Director of the Water Resources Research Institute, New Mexico State University, Las Cruces, N.M. 88003; Associate Professor, Department of Agronomy and Horticulture, New Mexico State University, Las Cruces, N.M. 88003; and former Research Aid (currently Research Assistant, Department of Range, Wildlife, and Fisheries Management, Texas Tech University, Lubbock, Tex. 79409).

\begin{abstract}
Off-road military vehicle traffic is a major consideration in the management of military lands. The objective of this study was to determine the impacts of military tracked M1A1 heavy combat tank vehicles on sediment loss from runoff, surface plant cover, and surface microtopography in a desert military training environment. A randomized block design was used which had 10 blocks with 4 plots $\left(0.5 \mathrm{~m}^{2}\right)$ in each block. Each block had randomly selected treatments that included an untreated control, 1 pass by a M1A1 tank under wet seasonal conditions, 3 passes by a M1A1 tank under wet seasonal conditions, 1 pass by a M1A1 tank under dry seasonal conditions, and 3 passes by a M1A1 tank under dry seasonal conditions. Data were analyzed using mean separation and stepwise regression techniques. Most sample periods showed that sediment losses from M1A1 tank treatments, single or triple passes under wet or dry seasonal conditions, did not differ statistically from natural sediment losses under nominal rainfall events. However, comparatively intense rainfall events often generated significantly $(P<0.05)$ greater sediment losses from the M1A1 tank triple pass treatments. Triple pass M1A1 tank impacts had detrimental effects that could last many years, particularly when disturbances were imposed under dry seasonal conditions. Seasonal drought for the area, occurring 2 out of 3 years during the study period, may have exacerbated the effects of triple pass M1A1 tank impacts. Analysis showed that grass cover, litter cover, and microtopographic variance were highly and negatively correlated $(R=$ -0.62) with cumulative sediment loss. Depending on precipitation availability, a minimum of 3 years for most triple pass M1A1 tank impacts is suggested for suitable vegetation recovery and soil stability. It is recommended that site repetitious M1A1 tank training maneuvers should be conducted with particular attention to site recovery. Furthermore, the influence of climate, drought in particular, should be among the topics addressed by future military training land use models.
\end{abstract}

Key Words: military land, soil stability, site recovery, seasonal drought

Management of military lands has historically, and logically, prioritized weapons testing and combat readiness over soil and water conservation. However, attention to environmental concerns and the National Environmental Policy Act (NEPA) is becoming increasingly prevalent on military reservations. Off-

Manuscript accepted 10 Sept. 02.

\section{Resumen}

El tráfico de vehículos militares fuera de los caminos (en campo traviesa) es una consideración importante en el manejo de los terrenos militares. El objetivo de este estudio fue determinar los impactos de los pesados tanques de combate M1A1 en las perdidas de sedimento en el escurrimiento, en la cobertura vegetal de la superficie y en la microtopografía de un ambiente desértico de entrenamiento militar. Se uso un diseño de bloques completos al azar el cual tenía 10 bloques con 4 parcelas $\left(0.5 \mathrm{~m}^{2}\right)$ en cada bloque. Cada bloque tenia tratamientos asignados aleatoriamente que incluyeron un control sin tratamiento, 1 paso de tanque M1A1 bajo condiciones de estación húmeda, 3 pasos de M1A1 bajo condiciones de estación húmeda, 1 paso del tanque M1A1 en condiciones de estación seca y 3 pasos de M1A1 bajo condiciones de estación seca. Los datos fueron analizados usando técnicas de separación de medias y regresión. La mayoría de los periodos de muestreo mostraron que perdidas de sedimento en los tratamientos del Tanque M1A1, uno o tres pasos, bajo condiciones de estación húmedo o seca, no difieren estadísticamente de las perdidas naturales que ocurren en los eventos nominales de lluvia. Sin embargo, los eventos de lluvia intensa a menudo generaron una perdida de sedimento significativamente mayor $(P<0.05)$ en los tratamientos de tres pasos de tanque M1A1. El paso triple de los tanques tuvo efectos detrimentales que pudieran durar muchos años, particularmente cuando los disturbios ocurrieron bajo condiciones de estación seca. La sequía estacional del área que ocurrió 2 de los 3 años del periodo de estudio puedo haber exacerbado los efectos del paso triple de los tanques M1A1. El análisis mostro que la cobertura de zacate y mantillo y la varianza microtopográfica estuvieron alta y negativamente correlacionados $(R=-0.62)$ con la pérdida acumulativa de sedimento. Dependiendo de la disponibilidad de lluvia, se sugiere que se requiere un mínimo de 3 años para una recuperación adecuada de la vegetación y estabilidad del suelo después de un paso triple de tanques M1A1. Se recomienda que las maniobras de entrenamiento de los tanques M1A1 repetitivas en un sitio deben conducirse poniendo particular atención en la recuperación del sitio. Mas aun, la influencia del clima, en particular la sequía, debe ser uno de los temas que deben abordarse en modelos futuros de uso de la tierra para entrenamiento militar.

road military vehicle traffic is a major consideration in the management of military lands (Severinghaus et al. 1979, Johnson 1982, Goran et al. 1983, Braunack 1986, Shaw and Diersing 1990, Diersing et al. 1990). Although formalized research may not be necessary to establish that damage does occur as a result of 
off-road vehicle traffic, quantified estimates of damage, specifically soil erosion, in response to variables such as soil type, precipitation, vegetation, soil surface microtopography, as well as kind and intensity of off-road vehicle traffic can provide a basis for managerial decisions. Military land managers are expected to maintain the natural resources, while military trainers are obligated to provide a realistic training experience (Diersing et al. 1990). A limited amount of information concerning off-road vehicle impacts is available from research on the effects of soil disturbance on the hydrological properties of agricultural (Van Doren 1959), forested lands (Moehring and Rawls 1970) and recreational lands (Eckert et al. 1979, Webb et al. 1983). However, information for site specific effects, military lands in particular, is slight. In 1974, Lathrop (1983) examined recovery since 1953 of Mojave Desert lands in California that had been impacted by military training from 1938 to 1942.

As the frequency and intensity of military training increases and the soil surface becomes further disturbed, the protective vegetation may be lost and soil erosion accelerated (Warren et al. 1991). If soil erosion is not monitored and management is not adjusted accordingly, extensive damage from gullying, sedimentation, and flooding may occur. This kind of damage is not only expensive to repair, but also diminishes the training realism and longterm use of military lands, as well as possibly jeopardizing the safety of soldiers and equipment. Military training exercises and associated off-road vehicle traffic are necessary to maintain combat readiness; therefore, attention to landscape training areas and associated soil erosion is necessary to implement effective and sustainable land management. The interrelationships between site soil and vegetation variables and the hydrologic impacts of tracked vehicle training exercises are often not considered by many military land managers.

The use of military tracked vehicles has been documented as particularly destructive of landscapes in military maneuvers (Goran et al. 1983, Braunack 1986, Shaw and Diersing 1990), primarily because military training exercises are generally not conducted with regard to landscape suitability (Diersing et al. 1990), but also because tracked vehicle track treads are inherently aggressive. Tracked vehicles are especially damaging to soil surfaces when the vehicle turns sharply (McKeys et al. 1980) because tracked vehicles require the track tread associated with the direction the vehicle is turning to stop or slow considerably, while the opposing tread propels the vehicle in the desired direction. This results in a skidding effect of the stationary track tread on the soil surface that crushes and uproots vegetation and compacts the soil (Prose et al. 1987, Diersing et al. 1990). The collapsed pore structure of the soil slows water infiltration, increases runoff, and may result in poor soil aeration which can inhibit recovery of the vegetation. Fragile landscapes can be disrupted for decades by a single tracked vehicle pass (Prose and Metzger 1985, Wilshire 1991).

\section{Materials and Methods}

\section{Site Description}

The study was conducted during 1994, 1995, and 1996 on the New Mexico portion of the Fort Bliss Military Reservation, within the McGregor Guided Missile Range of the Tularosa Basin. This area is about $160 \mathrm{~km}$ west of Las Cruces, N. M., at latitude $\mathrm{N} 32^{\circ} 11.515$ and longitude $\mathrm{W}$ $105^{\circ} 54.184$. The site is characterized by rolling hills at $1,219 \mathrm{~m}$ elevation with a southeastern exposure and slopes range from 5 to $20 \%$. The site contains Lozier series soils of the loamy-skeletal, carbonatic, thermic Lithic Calciorthid family. Typically, the surface layer is $18 \mathrm{~cm}$ thick. The substratum is very gravelly loam and very gravelly silty clay loam, generally 20 $\mathrm{cm}$ thick with a preponderance of lime. Unweathered limestone bedrock is at a depth of about $38 \mathrm{~cm}$. This soil is strongly calcareous throughout and moderately alkaline. Permeability is moderate. Available water capacity is very low, but the soil receives extra water as run-on from the limestone outcrop. This run-on has accelerated erosion on parts of the area. The area is a desert grassland comprised primarily of black grama (Bouteloua eriopoda Torr.) and dropseeds (Sporobolus spp.) with scattered yucca (Yucca spp.) and creosote (Larrea tridentata Cav.). The area climate is typical of the Tularosa Basin, where high intensity, low frequency, convectional rainstorms deposit the majority of moisture in the summer months of July, August, and September. The average annual precipitation is $203 \mathrm{~mm}$, and mean annual temperature ranges from 14 to $17^{\circ} \mathrm{C}$. The freezefree period averages 7 months ( 219 days), from early April to early November. Because precipitation is gener- ally low for the area, $80 \%$ of possible hours are occupied as sunshine, potential evapotranspiration usually approaches $2,540 \mathrm{~mm}$ year $^{-1}$, and relative humidity is typically no more than $65 \%$ in the early morning of the rainy season, rather dry soil moisture conditions persist (Derr 1981). Compounding the natural aridity of the area is strong wind, predominantly from the west or southwest in the spring. During the study, a seasonal drought characterized the basin climate with a preponderance of especially dry, windy conditions in April and May 1995 and 1996.

\section{Treatments and Sampling}

The study utilized a randomized block design with 2 areas chosen as replicates. The areas were chosen for similarity in slope $(\sim 5 \%)$. Each replicate area was randomly divided into several areas to be treated. Each area to be treated was called a pass by soil moisture condition plot. Pass referred to the number of vehicle passes across a plot, and soil moisture condition was either dry (late spring) or wet (late summer). Tank treatments were applied at the end of October 1994 (wet soil conditions), and tank treatments were applied at the end of March 1995 (dry soil conditions), i.e. 1 pass wet, 3 passes wet, 1 pass dry, and 3 passes dry. The military tracked vehicle used in this study was an M1A1 heavy combat tank. This tank weighs 58 metric tons (unarmed) and applies approximately $9,211 \mathrm{~kg} \mathrm{~m}^{-2}$ of standing ground pressure on the soil surface. Application of the tank treatments and spatial randomization was conducted under the direction of the U.S. Army's Environmental Division at Fort Bliss.

On each pass by season treatment within a replicate, 4 runoff plots $(0.5 \times 1.0 \mathrm{~m})$ were located. The plots were numbered 1 through 4 from the treatment area most downslope to the most upward, respectively. There were 8 plots per treatment resulting in 32 treated plots at the study site. Eight additional plots were installed, left untreated, and designated as control plots, resulting in a total of 40 plots. Plots were installed immediately after vehicle treatments and left for future evaluations (Eckert et al. 1979). Plots were constructed of sheet metal to form a $100 \mathrm{~mm}$ high border around the sides and top of the plot, and a runoff tray with a cover was placed on the downslope end of the plot. A hose was routed from the downslope end of the runoff tray to a sediment collection bucket buried outside the plot. Event rainfall was measured using a calibrated, Texas Electronics model 525 tipping-bucket rain 
gage attached to a Campbell Scientific model CR10X datalogger located at the study site near the plots. Following rainfall events, research personnel immediately gathered sediment from all sediment catch buckets and runoff trays. Sediment samples were taken to the watershed laboratory of New Mexico State University and were weighed after being oven-dried at $110^{\circ} \mathrm{C}$ for at least 48 hours (Gardner 1986). The weight of soil collected during each runoff event was tabulated. Event sediment weights for the 8 plots that make up a treatment were summed to produce a cumulative sediment weight for each treatment.

Plots were characterized by surface microtopography, vegetal cover $(\%)$, rock cover $(\%)$, and bareground $(\%)$. Soil surface microtopography was measured using a plot frame containing pins spaced $5 \mathrm{~cm}$ apart. The plot frame was located at a position interior and perpendicular to the plot at 20,50, and $80 \mathrm{~cm}$ from the bottom of the plot, as well as a position interior and parallel to the plot at $16 \mathrm{~cm}$ from each side of the plot (Sanchez and Wood 1987). Surface vegetation cover was measured as a percentage of the total area covered within each plot (Causton 1988) using the point method at the same points used to characterize soil surface microtopography (Cook and Stubbendieck 1986).

Sediment, surface microtopography, and surface vegetation cover data were subjected to statistical analysis to determine normality. The means of plot characteristics were compared with an analysis of variance and mean separation test (Least Significant Difference) at the 0.05, 0.10, and 0.20 levels of probability. Sediment loss was identified as a dependent variable, and soil surface microtopography and surface vegetation cover as independent variables. Stepwise regression was used to assess probable association of variables.

\section{Results and Discussion}

\section{Precipitation}

Figure 1 indicates weekly precipitation totals for 1994,1995 , and 1996 at the study site. Yearly totals were 192, 213, and $204 \mathrm{~mm}$ for 1994, 1995, and 1996, respectively. Although there is not much difference in the annual totals for all 3 years, there is considerable variation among years of those weeks where precipitation is concentrated. Weekly precipitation for 1994 indicated a comparatively even distribution of moisture, whereas 1995 and 1996 were characterized by especially wet periods late in summer and

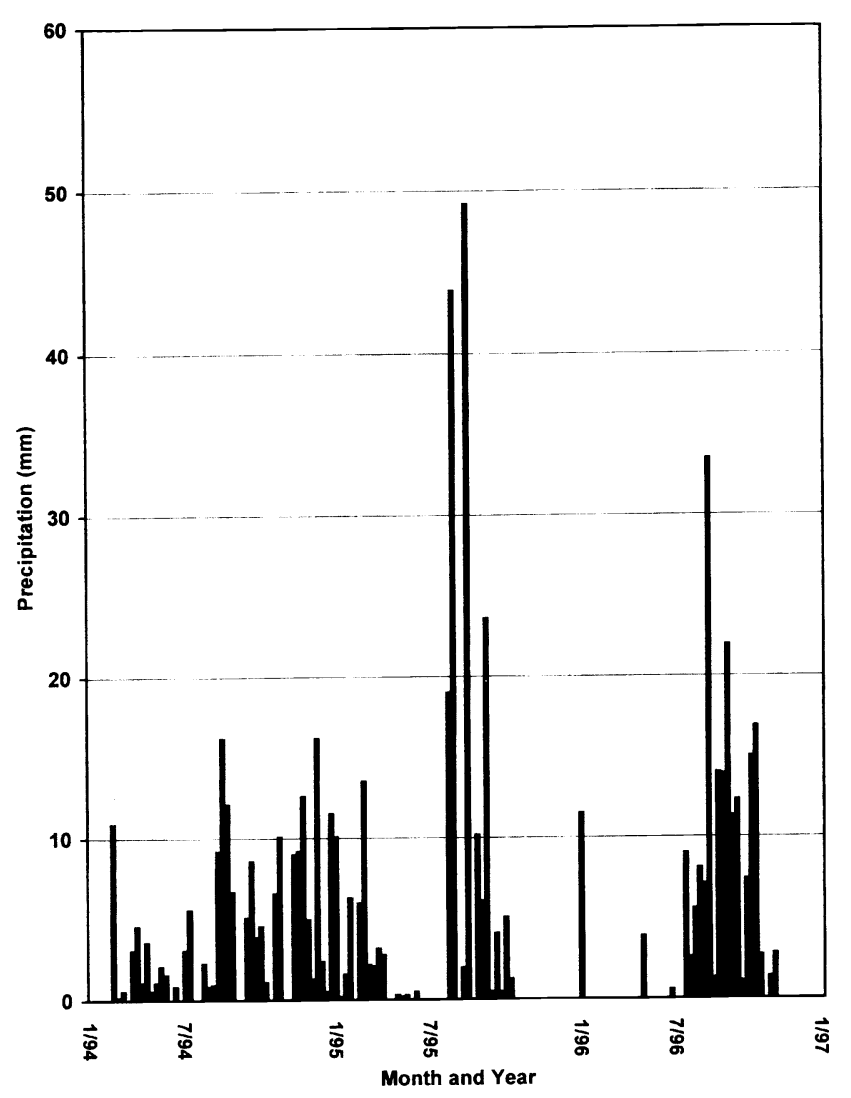

Fig. 1. Measured weekly total precipitation at the study site for 1994, 1995, and 1996.

especially dry periods in the spring, fall, and winter. Precipitation patterns during 1995 and 1996 were typical of the area climate with strong spring winds exacerbating the aridity and seasonal drought conditions for much of the study period.

Although considerable debate exists regarding the definition of drought conditions, a temporary regime of abnormal aridity that is detrimental to the naturally occurring plant community is generally recognized as less than $75 \%$ of average precipitation, and may be considered on an annual or seasonal basis (Cooke et al. 1993). Derr (1981) reported that average spring (March, April, and May) precipitation for the study area is $30 \mathrm{~mm}$. Spring (March, April, and May) precipitation at the study site for 1994, 1995, and 1996 was 21,7 , and $0 \mathrm{~mm}$, respectively, which was below the $75 \%$ drought threshold. Annual variation in soil moisture can have a profound influence on runoff and associated sediment loss (Thurow 1991), partly because drought conditions will generally increase the potential of water absorbed by a soil per unit soil surface area and unit time (infiltration rate). However, when a soil layer of different texture and permeability from the surface layer is present in the soil profile, it will reduce the infiltra- tion rate, regardless of whether it is coarser or finer than the surface layer (Jury et al. 1991). This may be a very important point, particularly since the Lozier soil series at the study site is rather shallow. Holes dug at the site to accommodate sediment collection buckets revealed that the depth to nearly impenetrable, impermeable calcium carbonate coated limestone was generally no more than 15 to $20 \mathrm{~cm}$. Given the porous, gravelly loam nature of the Lozier soil surface layer and inherently high potential infiltration capacity (maximum possible infiltration rate of the soil in a given condition) augmented by drought (Dunne and Leopold 1978), it seems plausible to assert that soil surface ponding might occur quite readily given the necessary magnitude of rainfall. Soil water acts as a binding agent for soil particles because of the cohesive force that it exerts when it occurs as an adsorbent film on soil particles (Jury et al. 1991), but once the soil's infiltration rate is achieved, additional moisture will leave the surface as runoff.

Rainfall intensity $\left(\mathrm{mm} \mathrm{hr}^{-1}\right)$ within a given storm event has long been correlated with infiltration, runoff, and erosion (Tricker 1981, Gifford 1985, Wood 1988, Brooks et al. 1991). Furthermore, individual exceptional storms have been documented as producing as much surface 


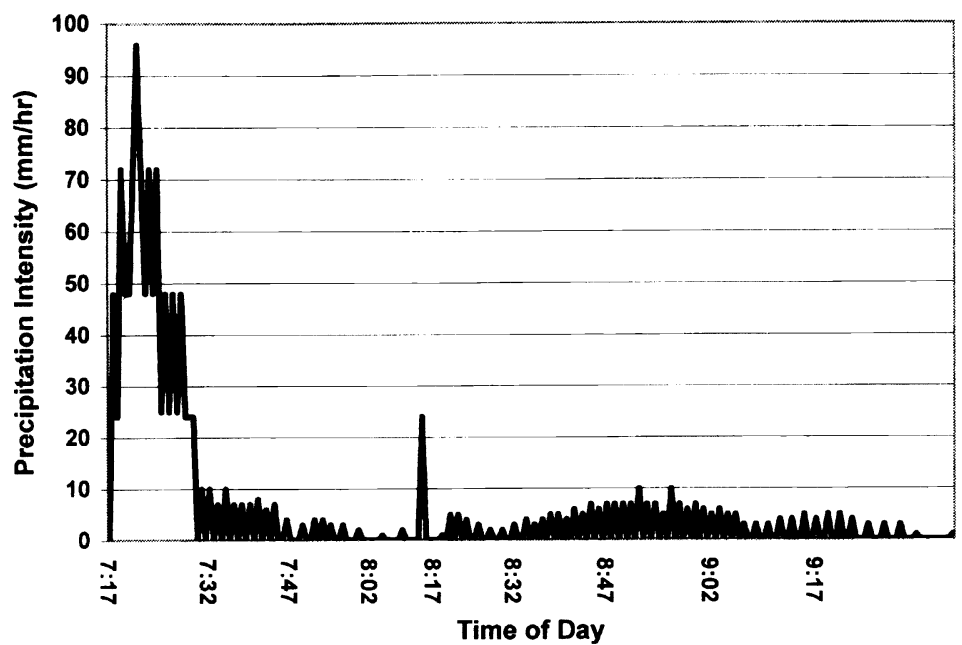

Fig. 2. Measured rainfall intensity for a select event of 2 hours and 34 min (morning of 30 June 1995) with a total rainfall of $17 \mathrm{~mm}$ and a maximum intensity of $96 \mathrm{~mm} / \mathrm{hr}$ at the study site.

runoff as several years of average runoff (Osborn and Renard 1969). Figure 2 depicts a simple pluviograph for a storm event occurring in late June 1995 at the study site that was among the most intense rainfall events that occurred during the study period. The intensity, volume, and timing of these events created considerable potential to produce runoff and subsequent sediment transport. The absence of sunlight and subsequent lowering of radiant energy to the soil surface, as well as associated lower temperatures, would tend to minimize immediate evaporation (Penman 1948). These events were also significant because they immediately followed the spring drought period of 1995. However, large concentrations of precipitation are not unknown to this area. For example, nearby La Luz, N.M. received $165 \mathrm{~mm}$ on 29 June 1950 (Derr 1981).

\section{Cumulative Sediment Loss}

Sediment is the product of the erosion process, which is usually defined as the detachment and transport of soil material on the earth surface (Brooks et al. 1991). Sediment loss occurs coincident with and as a consequence of almost immediately to intense rainfall events (Smith and Olyphant 1994). The correlation between sediment yield and precipitation is improved if the seasonality of precipitation is considered (Cooke et al. 1993). Erosion rates tend to be higher in areas of seasonal rainfall such as northeast Queensland, Australia, where the erosive impacts of intense storms is increased because the vegetation is relatively sparse because of the annual dry season (Douglas 1967).

Cumulative sediment loss and site precipitation data were compiled for the wet leveling periods among all treatments. The first of these occurred from 25 August

*Precipitation received through 10 days prior to the first sample period. ty; absence of letters indicates no significant differences.
1995 to 2 July 1996 . The second occurred at the end of the sampling periods, from 28 August to 20 September 1996 and was dominated by the triple pass tank treatments at $12,970 \mathrm{~kg} \mathrm{ha}^{-1}$ total sediment. Total cumulative sediment for controls was slightly less at $11,347 \mathrm{~kg} \mathrm{ha}^{-1}$. Mean separation tests indicate that the difference between the cumulative total on 20 September 1996 for triple pass tank treatments and controls is not significant, even at the 0.20 level of probability. The most dramatic increase in sediment loss for wet season treatments and all respective sampling periods occurred on the 7 July 1995 sampling date. Control, single pass, and triple pass treatments experienced cumulative sediment loss increases of $180 \%$, $153 \%$, and $154 \%$, respectively, during this period. Not surprisingly, these increases immediately follow the storm event discussed earlier (Fig. 2).

Dry season treatments' cumulative sediment loss (Table 2) indicated similar leveling periods as those of wet season losses, although the rate of erosion following dry season single and triple pass impacts was somewhat greater. The most substantial dry season treatments' total cumulative sediment losses at the end of the sam-

Table 1. Wet season treatments cumulative sediment loss and associated maximum daily precipitation.

\begin{tabular}{|c|c|c|c|c|c|c|}
\hline \multirow{2}{*}{$\begin{array}{l}\text { Sample } \\
\text { period }\end{array}$} & \multirow{2}{*}{$\begin{array}{c}\text { Total ppt. } \\
\text { since last } \\
\text { sample }\end{array}$} & \multirow{2}{*}{$\begin{array}{c}\text { Days } \\
\text { with ppt. }\end{array}$} & \multirow{2}{*}{$\begin{array}{c}\text { Max. daily } \\
\text { ppt. }\end{array}$} & \multicolumn{3}{|c|}{ Cumulative sediment loss** } \\
\hline & & & & Control & 1 pass & 3 pass \\
\hline & $(\mathrm{mm})$ & (No.) & $(\mathrm{mm})$ & \multicolumn{3}{|c|}{ 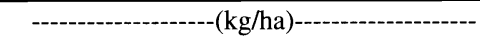 } \\
\hline $5 / 11 / 94$ & $9.1^{*}$ & 1 & 9.1 & 330.3 & 344.3 & 514.8 \\
\hline $25 / 11 / 94$ & 26.1 & 7 & 11.6 & 401.3 & 369.6 & 582.6 \\
\hline $16 / 12 / 94$ & 19.7 & 4 & 10.6 & $460.3 \mathrm{a}$ & $405.5 \mathrm{a}$ & $711.6 b$ \\
\hline $11 / 1 / 95$ & 22.2 & 9 & 10.3 & $560.5 a$ & $513.5 \mathrm{a}$ & $941.4 b$ \\
\hline $17 / 2 / 95$ & 27.7 & 10 & 9.3 & $716.0 \mathrm{a}$ & $601.5 \mathrm{a}$ & $1,147.4 b$ \\
\hline $22 / 3 / 95$ & 9.7 & 6 & 3.1 & $827.5 \mathrm{a}$ & $714.3 \mathrm{a}$ & $1,315.9 b$ \\
\hline $23 / 5 / 95$ & 1.5 & 6 & 0.6 & $955.3 \mathrm{a}$ & $772.3 \mathrm{a}$ & $1,440.1 \mathrm{~b}$ \\
\hline $23 / 6 / 95$ & 18.9 & 4 & 12.1 & $1,270.8 \mathrm{a}$ & $1,392.5 \mathrm{a}$ & $2,115.1 b$ \\
\hline $29 / 6 / 95$ & 15.4 & 3 & 9.7 & $1,682.8 \mathrm{a}$ & $1,730.5 \mathrm{a}$ & $2,512.9 b$ \\
\hline $7 / 7 / 95$ & 28.4 & 1 & 28.4 & $2,990.5 \mathrm{ab}$ & $2,642.5 \mathrm{a}$ & $3,863.1 \mathrm{~b}$ \\
\hline $21 / 7 / 95$ & 35.9 & 5 & 12.7 & $3,317.3 \mathrm{ab}$ & $3,078.5 \mathrm{a}$ & $4,099.6 b$ \\
\hline $27 / 7 / 95$ & 15.0 & 1 & 15.0 & $4,891.3$ & $4,365.0$ & $4,954.0$ \\
\hline $10 / 8 / 95$ & 16.2 & 4 & 7.0 & $5,090.3$ & $4,560.5$ & $5,207.9$ \\
\hline $17 / 8 / 95$ & 10.8 & 4 & 4.9 & $5,209.5$ & $4,776.5$ & $5,394.1$ \\
\hline $25 / 8 / 95$ & 13.1 & 2 & 12.7 & $7,239.3$ & $6,076.8$ & $7,303.9$ \\
\hline $11 / 9 / 95$ & 6.4 & 6 & 2.8 & $7,379.0$ & $6,218.0$ & $7,437.0$ \\
\hline $21 / 9 / 95$ & 4.1 & 7 & 2.0 & $7,436.3$ & $6,307.3$ & $7,536.9$ \\
\hline $26 / 6 / 96$ & 33.4 & 9 & 11.3 & $7,697.0$ & $6,615.0$ & $7,819.0$ \\
\hline 2/7/96 & 8.2 & 3 & 6.1 & $7,817.0$ & $6,793.0$ & $8,024.0$ \\
\hline $12 / 7 / 96$ & 12.9 & 3 & 5.9 & $9,510.0$ & $9,063.0$ & $10,505.0$ \\
\hline $19 / 7 / 96$ & 28.8 & 4 & 16.8 & $10,141.0$ & $9,618.0$ & $11,262.0$ \\
\hline 2/8/96 & 28.0 & 5 & 13.8 & $10,351.0$ & $10,119.0$ & $11,818.0$ \\
\hline $28 / 8 / 96$ & 46.9 & 11 & 12.6 & $11,185.0$ & $10,589.0$ & $12,798.0$ \\
\hline 4/9/96 & 7.0 & 3 & 4.8 & $11,318.0$ & $10,658.0$ & $12,927.0$ \\
\hline $20 / 9 / 96$ & 15.5 & 4 & 14.7 & $11,347.0$ & $10,681.0$ & $12,970.0$ \\
\hline
\end{tabular}

**Means followed by the same letter within a sample period are not significantly different at the $10 \%$ level of probabili- 
Table 2. Dry season treatments cumulative sediment loss and associated maximum daily precipitation.

\begin{tabular}{|c|c|c|c|c|c|c|}
\hline \multirow{2}{*}{$\begin{array}{l}\text { Sample } \\
\text { period }\end{array}$} & \multirow{2}{*}{$\begin{array}{l}\text { Total ppt. } \\
\text { since last } \\
\text { sample }\end{array}$} & \multirow{2}{*}{$\begin{array}{c}\text { Days } \\
\text { with ppt. }\end{array}$} & \multirow{2}{*}{$\begin{array}{c}\text { Max. daily } \\
\text { ppt. }\end{array}$} & \multicolumn{3}{|c|}{ Cumulative sediment loss $* *$} \\
\hline & & & & Control & 1 pass & 3 pass \\
\hline & $(\mathrm{mm})$ & (No.) & $(\mathrm{mm})$ & \multicolumn{3}{|c|}{ - } \\
\hline $5 / 11 / 94$ & $18.9 *$ & 4 & 12.1 & $315.5 \mathrm{a}$ & $458.0 \mathrm{ab}$ & $581.2 \mathrm{~b}$ \\
\hline $29 / 6 / 95$ & 15.4 & 9.7 & $727.5 \mathrm{a}$ & $1,116.2 b$ & $1429.2 \mathrm{c}$ & \\
\hline $7 / 7 / 95$ & 28.4 & 1 & 28.4 & $2,035.3 \mathrm{a}$ & $2,115.9 a$ & $3,390.7 \mathrm{~b}$ \\
\hline $21 / 7 / 95$ & 35.9 & 5 & 12.7 & $2,362.1 \mathrm{a}$ & $2,703.7 \mathrm{a}$ & $3,856.2 b$ \\
\hline $27 / 7 / 95$ & 15.0 & 1 & 15.0 & $3,936.0 \mathrm{a}$ & $3,987.0 \mathrm{ab}$ & $5,026.3 b$ \\
\hline $10 / 8 / 95$ & 16.2 & 4 & 7.0 & $4,135.0$ & $4,142.2$ & $5,247.5$ \\
\hline $17 / 8 / 95$ & 10.8 & 4 & 4.9 & $4,254.3 \mathrm{a}$ & $4,327.0 \mathrm{a}$ & $5,496.8 b$ \\
\hline $25 / 8 / 95$ & 13.1 & 2 & 12.7 & $6,284.0$ & $5,504.1$ & $6,652.8$ \\
\hline $11 / 9 / 95$ & 6.4 & 6 & 2.8 & $6,423.8$ & $5,638.6$ & $6,832.0$ \\
\hline $21 / 9 / 95$ & 4.1 & 7 & 2.0 & $6,481.0$ & $5,732.4$ & $6,936.5$ \\
\hline $26 / 6 / 96$ & 33.4 & 9 & 11.3 & $6,742.0$ & $5,966.0$ & $7,374.0$ \\
\hline $2 / 7 / 96$ & 8.2 & 3 & 6.1 & $6,862.0$ & $6,218.0$ & $7,722.0$ \\
\hline $12 / 7 / 96$ & 12.9 & 3 & 5.9 & $8,555.0 \mathrm{a}$ & $8,464.0 \mathrm{a}$ & $13,971.0 \mathrm{~b}$ \\
\hline $19 / 7 / 96$ & 28.8 & 4 & 16.8 & $9,186.0 \mathrm{a}$ & $9,227.0 \mathrm{a}$ & $14,583.0 \mathrm{~b}$ \\
\hline $2 / 8 / 96$ & 28.0 & 5 & 13.8 & $9,396.0 \mathrm{a}$ & $9,716.0 \mathrm{a}$ & $15,147.0 \mathrm{~b}$ \\
\hline $28 / 8 / 96$ & 46.9 & 11 & 12.6 & $10,230.0 \mathrm{a}$ & $10,332.0 \mathrm{a}$ & $15,980.0 \mathrm{~b}$ \\
\hline 4/9/96 & 7.0 & 3 & 4.8 & $10,363.0 \mathrm{a}$ & $10,609.0 \mathrm{a}$ & $16,173.0 \mathrm{~b}$ \\
\hline $20 / 9 / 96$ & 15.5 & 4 & 14.7 & $10,392.0 \mathrm{a}$ & $10,661.0 \mathrm{a}$ & $16,264.0 \mathrm{~b}$ \\
\hline
\end{tabular}

*Precipitation received through 10 days prior to the first sample period.

***Means followed by the same letter within a sample period are not significantly different at the $10 \%$ level of probability; absence of letters indicates no significant differences.

pling periods were associated with triple pass tank treatments at $16,264 \mathrm{~kg} \mathrm{ha}^{-1}$. Control and single pass treatment total cumulative losses were essentially identical and statistically similar at 10,392 and $10,661 \mathrm{~kg} \mathrm{ha}^{-1}$, respectively, even at the 0.20 level of probability. Cumulative sediment losses for triple pass tank treatments were significantly greater $(\mathrm{P}<0.05)$ than control or single pass treatments from 12 July 1996 through the final 20 September 1996 sampling period. Other researchers have reported similar findings under dry conditions. For example, Wilcox and Wood (1986) found that sediment loss was greater in dry areas, regardless of slope.

Like wet season results, the most dramatic increase in sediment loss for dry season treatments occurred on the 7 July 1995 sampling date. Control, single pass, and triple pass treatments experienced cumulative sediment loss increases of $280 \%, 190 \%$, and $240 \%$, respectively, during this period. The control (no disturbance) response to the exceptional storm events in late June 1995 (Fig. 2) was greater than single or triple pass treatments, regardless of season. This suggests that timing and intensity of precipitation, as well as antecedent soil moisture conditions, may have had a greater influence on the Lozier soil series and associated sediment loss at this site than the impact of 1 or 3 pass M1A1 tank disturbances. However, as stated by Parsons et al. (1994), there may be no specific temporal pattern to the soil detachment process controlling sediment loss in runoff, thereby suggesting that different temporal patterns of sediment loss can be found even from the same location on different occasions. In contrast, Hairsine and Rose (1992) reported that sediment loss can fluctuate with time between an upper transport limit reflecting the ability of runoff to carry sediment, and a lower source limit that depends on the soil surface strength or resistance to removal of soil by runoff. Therefore, it seems plausible that even a single pass by an M1A1 tank, an infantry foot soldier, or a naturally occurring grazing herbivore would all have some deflation impact on the soil surface and thereby lower the soil surface strength or resistance to removal of soil by runoff, but the impacts are probably temporary.

Derr (1981) estimated that a Lozier soil series in this area can sustain an average maximum rate of $2,242 \mathrm{~kg} \mathrm{ha}^{-1} \mathrm{yr}^{-1}$ of sediment loss without reducing environmental quality. Measured losses for control treatments (no disturbance) during the study period averaged $7,192 \mathrm{~kg} \mathrm{ha}^{-1} \mathrm{yr}^{-1}$. Measured losses for wet season treatments during the study period averaged 6,085 and $7,437 \mathrm{~kg} \mathrm{ha}^{-1} \mathrm{yr}^{-1}$ for single and triple pass treatments, respectively. Measured losses for dry season treatments during the study period averaged 6,056 and $8,053 \mathrm{~kg}$ $\mathrm{ha}^{-1} \mathrm{yr}^{-1}$ for single and triple pass treatments, respectively. The average annual sediment losses from control treatments during the study period were 3.2 times greater than the tolerance estimate (Tvalue) provided by Derr (1981). Assuming that Derr's estimate was even remotely accurate, then further consideration should be given to the earlier suggestion that timing and intensity of precipitation, as well as antecedent soil moisture conditions, may have far greater implications on sediment loss in the Lozier soil series at this site than the impact of 1 or 3 pass M1A1 tank disturbances. However, T-value provided by Derr (1981) in the soil survey for the study site is among a family of estimates generally criticized as being somewhat arbitrary, reflecting societal and political views rather than science (McCormack et al. 1979). For example, Wight and Siddoway (1981) stated that Tvalues for rangelands may be a concept with only an idealistic application.

Although observance of seasonal drought and variable precipitation during the study period may provide some merit in accepting the reported levels of sediment loss, particularly in the absence of disturbance, it should be noted that precipitation has historically varied greatly from year to year and from month to month in the study area. For example, Derr (1981) reported that at nearby Orogrande, N.M., $573 \mathrm{~mm}$ of precipitation fell in 1905 and $75 \mathrm{~mm}$ fell in 1934. At nearby Tularosa, N.M., $249 \mathrm{~mm}$ fell in September 1941 and none in September 1918. The consideration of variable climates' contribution to soil erosion is certainly not new. Langbein and Schumm (1958) suggest that the variation in sediment yield with climate can be explained by the balancing of 2 opposing forces, each related to precipitation. The erosive influence of precipitation increases with its amount through its direct impact in eroding soil and in generating runoff with further capacity for erosion and transportation. Opposing this influence is the effect of vegetation, which tends to increase in surface area cover with increasing annual precipitation.

\section{Surface Vegetation Cover}

Plant cover is an important variable in water distribution on rangelands for 3 primary reasons. First, plants intercept raindrops, thereby reducing surface sealing and soil detachment by raindrops (Wood et al. 1998). Second, plant stems and litter increase surface roughness and hydraulic resistance, decreasing surface runoff velocity (Wood et al. 1994). Third, plant roots bind soil and diminish soil erodibility (Wischmeier and Smith 1978, Lee 
1980, Branson et al. 1981, Thompson and James 1985, Abrahams et al. 1988, Johnson and Gordon 1988, Brooks et al. 1991, Thurow 1991, Satterlund and Adams 1992). In amenable contrast, however, Rogers and Schumm (1991) suggest that plant cover influences on runoff and sediment loss may be both positive and negative. In their view, vegetation results in the disruption of overland flow, and flow across a surface can be both concentrated, as well as deflected and dispersed by individual vegetation obstructions. Deflection reduces velocity, which reduces the erosive ability of flow, whereas concentration of flow increases velocity and depth which causes quicker initiation of erosion and deeper scour of rills on surfaces with low ground cover. Mean surface vegetation cover is reported as a percentage of the components grass, forb, shrub, litter, total plant, rock, and bare ground of the total plot area at each sample date for each treatment.

Grass cover is considered among the most effective agents in promoting soil stability because the fine, adventitious grass root tissues cover an extensive subsurface area relative to the area of the grass crown and tend to secure soil particles (Wischmeier and Smith 1978). Measurement of grass cover revealed low percentages (Table 3). The 4 November 1995 sample period produced the lowest cover values for all treatments, coinciding with little or no precipitation. Vegetation cover is a particularly useful measurement tool for perennial species as it responds more acutely to seasonal climatic fluctuation (particularly drought) than density measurements (Bonham 1989). Despite the recorded seasonal aridity among all sample periods, the control plots produced appreciable mean grass cover. Table 3 indicates that all other treatment means are significantly less $(\mathrm{P}>0.20)$ than control means under wet and dry season condition treatments at every sampling period. The triple pass tank (dry) treatments produced less mean grass cover $(P>0.20)$ than single pass (dry) treatments at every sampling period. The final sample period revealed mean control grass cover at $21 \%$ (dry) and $21 \%$ (wet) and single pass tank (wet) and single pass tank (dry) treatments at 13 and $13 \%$, respectively, each not significantly different from the control at the 0.05 level of probability.

As a percentage of plot area, mean forb cover was comparatively scarce ranging from 0 to just over $3 \%$ (Table 4). Tall, slender stems tend to make forbs less effective in preventing sediment loss
Table 3. Mean grass cover at several sampling periods and significant differences at several levels of probability with wet and dry season treatments.

\begin{tabular}{|c|c|c|c|c|}
\hline \multirow[t]{2}{*}{ Treatment } & \multirow{2}{*}{$\frac{\text { Mean }}{(\%)^{*}}$} & \multicolumn{3}{|c|}{ Level of probability } \\
\hline & & $\underline{0.05}$ & $\underline{0.10}$ & $\underline{0.20}$ \\
\hline 28/3/95 & & & & \\
\hline Control & 14.50 & $\mathrm{a}$ & $\mathrm{a}$ & $\mathrm{a}$ \\
\hline Tank 1 Pass Dry & 8.52 & $\mathrm{~b}$ & b & $\mathrm{b}$ \\
\hline Tank 3 Pass Dry & 2.08 & c & c & c \\
\hline $4 / 11 / 95$ & & & & \\
\hline Control & $10.21 \mathrm{a}$ & $\mathrm{a}$ & $\mathrm{a}$ & \\
\hline Tank 1 Pass Dry & 4.91 & $\mathrm{~b}$ & $\mathrm{~b}$ & $\mathrm{~b}$ \\
\hline Tank 3 Pass Dry & 1.70 & $\mathrm{~b}$ & $\mathrm{~b}$ & c \\
\hline Date: $26 / 10 / 9$ & & & & \\
\hline Contro & 21.02 & $\mathrm{a}$ & $\mathrm{a}$ & $\mathrm{a}$ \\
\hline Tank 1 Pass Dry & 13.46 & $a b$ & $\mathrm{~b}$ & $\mathrm{~b}$ \\
\hline Tank 3 Pass Dr & 6.64 & $\mathrm{~b}$ & $\mathrm{~b}$ & $\mathrm{c}$ \\
\hline $28 / 3 / 95$ & & & & \\
\hline Control & 14.41 & $\mathrm{a}$ & a & $\mathrm{a}$ \\
\hline Tank 1Pass Wet & 8.71 & b & b & $\mathrm{b}$ \\
\hline Tank 3 Pass Wet & 3.59 & c & c & $\mathrm{c}$ \\
\hline Date: $\quad 4 / 11 / 95$ & & & & \\
\hline Control & 10.21 & $\mathrm{a}$ & a & a \\
\hline Tank 1 Pass Wet & 2.26 & $\mathrm{~b}$ & $\mathrm{~b}$ & b \\
\hline Tank 1 Pass Wet & 3.21 & $\mathrm{~b}$ & $\mathrm{~b}$ & $\mathrm{~b}$ \\
\hline $26 / 10 / 96$ & & & & \\
\hline Control & 21.05 & $\mathrm{a}$ & a & $\mathrm{a}$ \\
\hline Tank 1 Pass Wet & 13.44 & $a b$ & $\mathrm{~b}$ & b \\
\hline Tank 1 Pass Wet & 7.59 & $\mathrm{~b}$ & $\mathrm{~b}$ & c \\
\hline
\end{tabular}

Table 4. Mean forb cover at several sampling periods and significant differences at several levels of probability with wet and dry season treatments.

\begin{tabular}{|c|c|c|c|c|}
\hline Treatment & \multirow{2}{*}{$\frac{\text { Mean }}{(\%)^{*}}$} & \multicolumn{3}{|c|}{ Level of probability } \\
\hline $28 / 3 / 95$ & & $\underline{0.05}$ & $\underline{0.10}$ & $\underline{0.20}$ \\
\hline Control & 0 & - & - & - \\
\hline Tank 1 Pass Dry & 0 & - & - & - \\
\hline Tank 3 Pass Dry & 0 & - & - & - \\
\hline $4 / 11 / 95$ & & & & \\
\hline Control & 0.75 & $\mathrm{a}$ & a & a \\
\hline Tank 1 Pass Dry & 0.94 & a & a & a \\
\hline Tank 3 Pass Dry & 1.70 & a & a & a \\
\hline $26 / 10 / 96$ & & & & \\
\hline Control & 0.19 & a & a & $\mathrm{a}$ \\
\hline Tank 1 Pass Dry & 0.75 & a & a & a \\
\hline Tank 3 Pass Dry & 0.75 & a & a & a \\
\hline $28 / 3 / 95$ & & & & \\
\hline Control & 0 & - & - & - \\
\hline Tank 1 Pass Wet & 0 & - & - & - \\
\hline Tank 3 Pass Wet & 0 & - & - & - \\
\hline te: $\quad 4 / 11 / 95$ & & & & \\
\hline Control & 0.75 & a & a & b \\
\hline Tank 1 Pass Wet & 2.65 & $\mathrm{a}$ & $\mathrm{a}$ & $a b$ \\
\hline Tank 3 Pass Wet & 2.84 & a & a & $\mathrm{a}$ \\
\hline $26 / 10 / 96$ & & & & \\
\hline Control & 0.19 & b & b & b \\
\hline Tank 1 Pass Wet & 3.02 & $\mathrm{a}$ & $\mathrm{a}$ & a \\
\hline Tank 3 Pass Wet & 2 & a & a & $\mathrm{a}$ \\
\hline
\end{tabular}

*Means followed by the same letter within a sample date and probability level are not significantly different. 
Table 5. Mean shrub cover at several sampling periods and significant differences at several levels of probability with wet and dry season treatments.

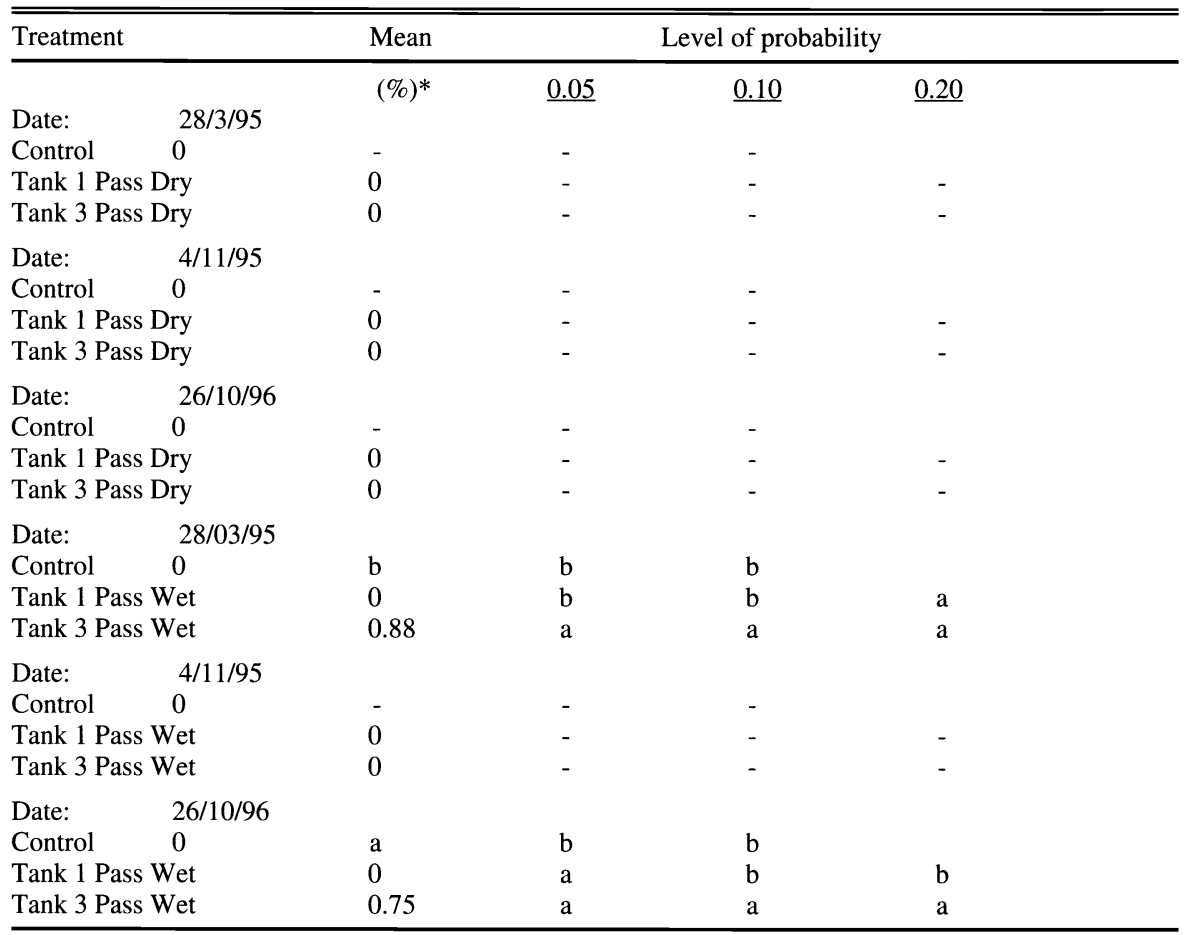

*Means followed by the same letter within a sample date and probability level are not significantly different.

through raindrop interception, as well as poor soil stabilization due to less extensive root development. Forbs were generally only seen during the study period as occupying tank impacts associated with the study. Since many of the forbs in the study area are annuals, dependence upon yearly germination of seed is vital for survival. Forbs are largely opportunistic, frequently taking root in soil conditions conducive to growth. Such conditions are often disturbed areas, like the tank treatments of this study. With the exception of control plots compared with wet season results at the 4 November 1995 and 26 October 1996 sample dates, no significant differences $(\mathrm{P}$ $>0.20$ ) of mean forb cover were found between any treatments or sampling periods. Mean forb cover was highest on single pass tank (wet) treatments of $3.02 \%$ at the final, 26 October 1996 sample period.

Mean shrub cover was lower $(<1 \%$ for all treatments) than forb cover (Table 5). The highest shrub cover was observed at the first sampling, 28 March 1995, and occurred on the triple pass tank (wet) treatments at a mean of $0.88 \%$. Interestingly, this same treatment hosted no shrub occurrence on the second sampling period, but appeared again at a mean of $0.75 \%$ on the final, 26 October 1996 sample period. This sporadic behavior is likely a result of the nature of the shrub, or half-shrub in this case, broom snakeweed (Gutierrezia sarothrae Shinners). Snakeweed is a perennial half-shrub that commonly undergoes cyclic fluctuations in population densities due to seasonal climatic variation (Vallentine 1974). There were no significant differences $(0.20$ probability) among the respective means of basal shrub covers at any sampling period among dry season treatments, but control (wet) season treatment cover was less $(\mathrm{P}>$ 0.20 ) than triple pass tank impacts on 28 March 1995, as well as on 26 October 1996.

Litter cover was the most abundant plant-related property on the surface of all treatments. Though not immediately useful from the standpoint of a soil-binding agent, litter cover does help protect the soil surface from the erosive forces of raindrop energy through interception. Table 6 shows results were quite variable among treatments and between sampling periods. The 4 November 1995 sampling period, however, illustrates general agreement among treatments. At this period, all treatment means, with the exception of triple pass tank (dry), exhibited no significant differences at the 0.20 level of probability. Other results of mean litter cover are less clear, most likely due to the influence of wind at the site between sampling periods. Surface organic material is commonly dry and lightweight, and vegetal portions are readily moved by the forces of wind. Many desert rangeland plants rely

Table 6. Mean litter cover at several sampling periods and significant differences at several levels of probability with wet and dry season treatments.

\begin{tabular}{|c|c|c|c|c|}
\hline Treatment & \multirow{2}{*}{$\frac{\text { Mean }}{(\%)^{*}}$} & \multicolumn{3}{|c|}{ Level of probability } \\
\hline & & $\underline{0.05}$ & $\underline{0.10}$ & $\underline{0.20}$ \\
\hline $28 / 3 / 95$ & & & & \\
\hline Control & 32.20 & $\mathrm{~b}$ & b & $\mathrm{b}$ \\
\hline Tank 1 Pass Dry & 43.37 & a & a & a \\
\hline Tank 3 Pass Dry & 21.21 & $\mathrm{c}$ & c & c \\
\hline $4 / 11 / 95$ & & & & \\
\hline Control & 33.71 & $\mathrm{a}$ & a & $\mathrm{a}$ \\
\hline Tank 1 Pass Dry & 32.96 & a & a & a \\
\hline Tank 3 Pass Dry & 15.15 & $\mathrm{~b}$ & b & $\mathrm{b}$ \\
\hline $26 / 10 / 96$ & & & & \\
\hline Control & 28.40 & a & a & a \\
\hline Tank 1 Pass Dry & 30.49 & $\mathrm{a}$ & a & a \\
\hline Tank 3 Pass Dry & 25.79 & $\mathrm{a}$ & a & $\mathrm{a}$ \\
\hline $28 / 03 / 95$ & & & & \\
\hline Control & 32.20 & $\mathrm{a}$ & $\mathrm{a}$ & b \\
\hline Tank 1 Pass Wet & 46.21 & $\mathrm{a}$ & a & a \\
\hline Tank 3 Pass Wet & 37.50 & $\mathrm{a}$ & a & $\mathrm{a}$ \\
\hline $4 / 11 / 95$ & & & & \\
\hline Control & 33.71 & $\mathrm{a}$ & a & a \\
\hline Tank 1 Pass Wet & 33.90 & $\mathrm{a}$ & a & a \\
\hline Tank 3 Pass Wet & 3.35 & $\mathrm{a}$ & a & $\mathrm{a}$ \\
\hline $26 / 10 / / 96$ & & & & \\
\hline Control & $27.40 \mathrm{~b}$ & $\mathrm{~b}$ & b & \\
\hline Tank 1 Pass Wet & 45.44 & $\mathrm{a}$ & a & $\mathrm{a}$ \\
\hline Tank 3 Pass Wet & 32.68 & $\mathrm{~b}$ & b & $\mathrm{b}$ \\
\hline
\end{tabular}

*Means followed by the same letter within a sample date and probability level are not significantly different. 
Table 7. Mean total plant cover at several sampling periods and significant differences at several levels of probability with wet and dry season treatments.

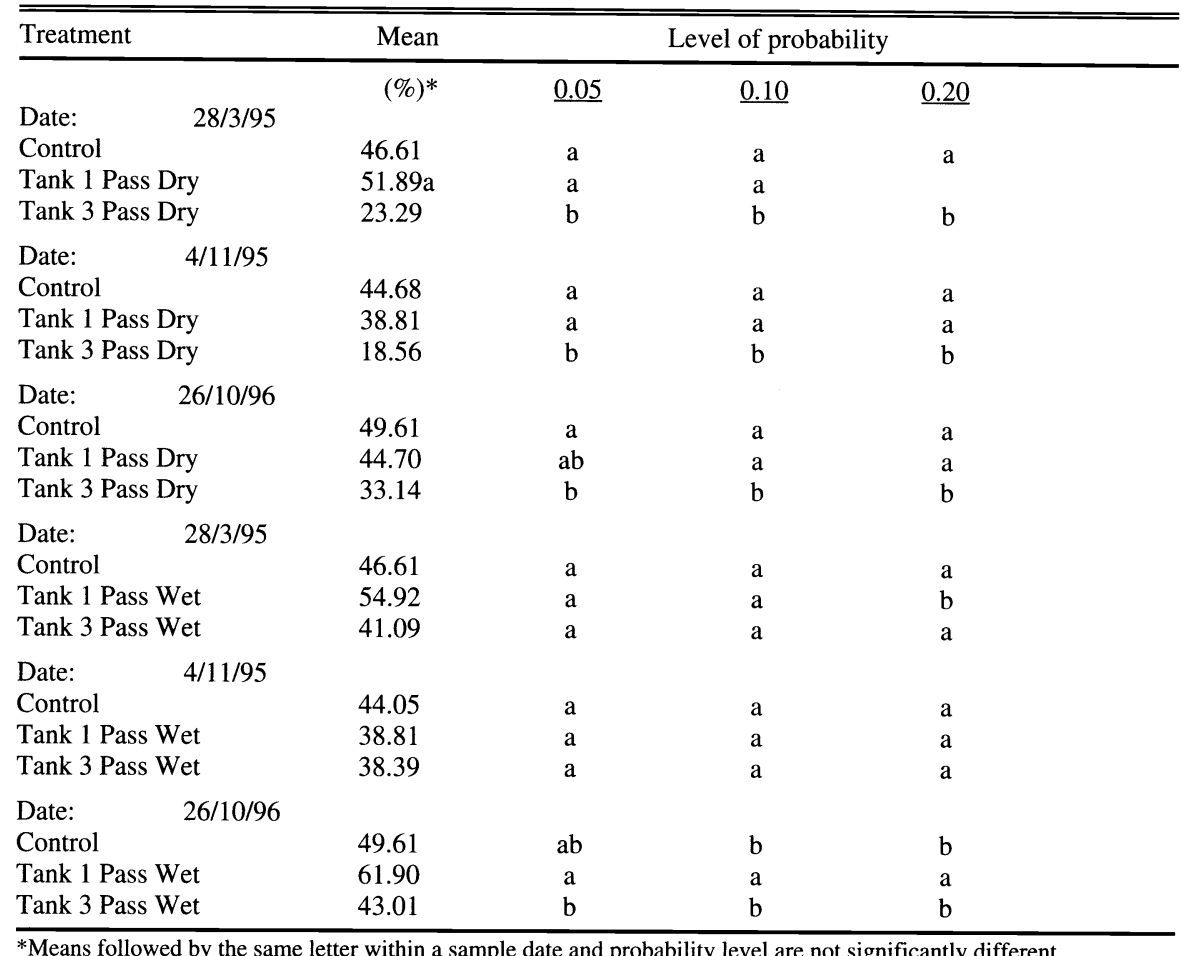

on wind to aid in the transport and distribution of seed. The final sample period, 26 October 1996, exhibited greater litter cover $(45 \%)$ for single pass tank (wet) treatments than for $(\mathrm{P}<0.05)$ other treatments. This is probably a result of forb colonization and is useful from the standpoints of retaining soil moisture and building soil organic matter.

The culmination of surface vegetation is reported as total plant cover (Table 7). This measure is simply the addition of the individual mean grass, forb, shrub, and litter components previously determined. As expected, the control means remained fairly consistent between sampling periods, ranging from a low of $45 \%$ on 4 November 1995 to a high of $50 \%$ on 26 October 1996. The triple pass tank (dry) treatments consecutively and significantly produced less $(\mathrm{P}>0.20)$ total plant cover than all other treatments at every sampling period. Single pass tank (wet) treatments yielded appreciable plant cover at all sampling periods and was significantly the highest $(P<0.20)$ of all periods on 26 October 1996 at $62 \%$. The foremost contributing component of total plant cover for all treatments was litter. Therefore, some of the variation that occurred among treatments and between sampling periods may be explained by the same confounding influence of wind described for mean litter cover values. While litter is a property of vegetation, and it is certainly beneficial in curtailing sediment dislocation, lit-

Table 8. Mean rock cover at several sampling periods and significant differences at several levels of probability with wet and dry season treatments.

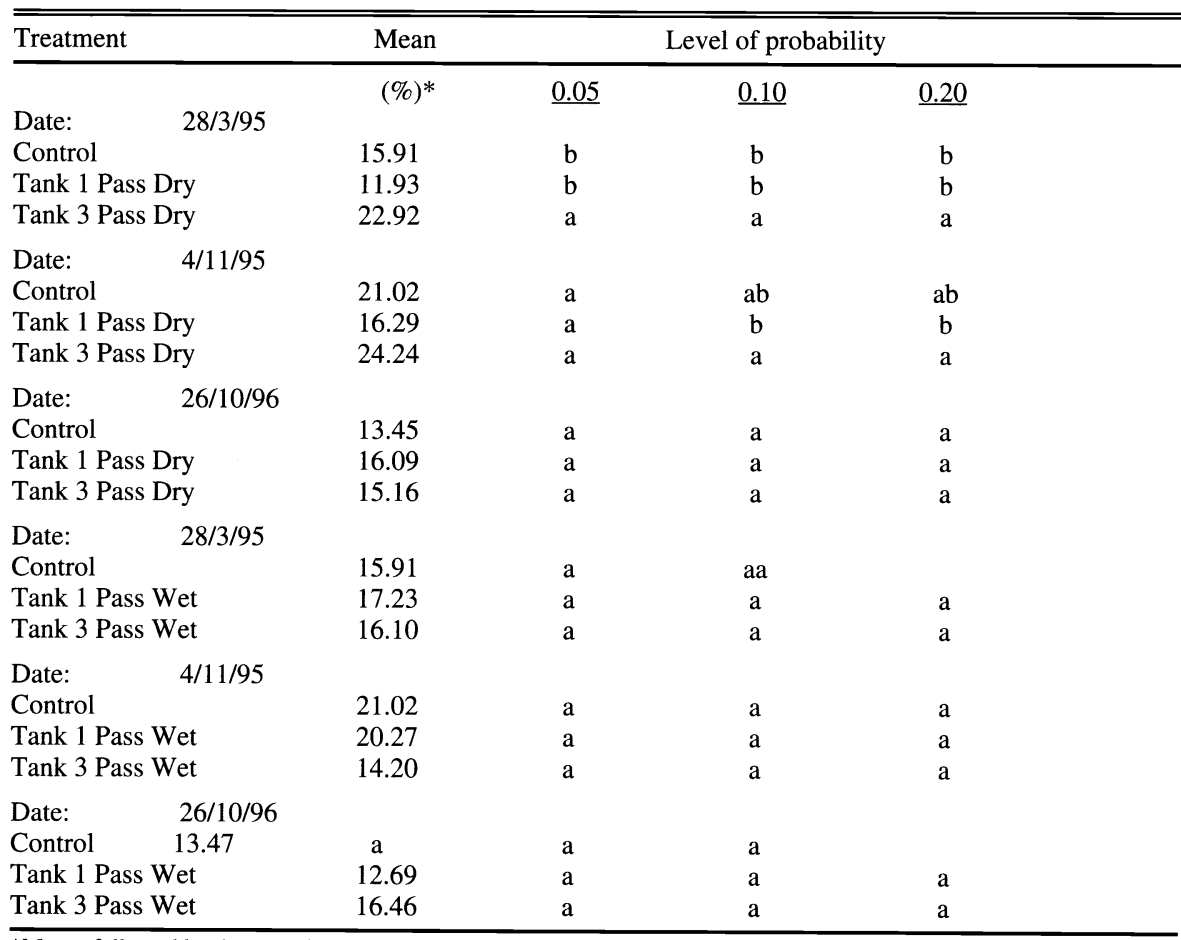

ter should probably not be considered as prominent as established vegetation for soil stabilization media.

Rock cover is also an important surface feature of desert landscapes because it exerts exceptional control on surface stability. Rock cover commonly acts as a barrier to processes impacting the surface, and in this sense can be seen as a substitute in aridity for otherwise sparse vegetation. Table 8 shows, with the exception of the final sampling period, that triple pass tank (dry) treatments exhibited the most mean rock cover. These treatments represented the most disturbed areas in terms of sediment loss and total plant denudation. However, because of this disturbance, it appears that coarse particles remained on the surface after finer materials had been dislodged by raindrop erosion and removed by runoff. The remaining coarse particles account for much of the measured rock cover. Triple pass tank (dry) treatments were highest on the 4 November 1995 sampling period at $24 \%$, though not significantly $(P>0.20)$ greater than controls.

Bare ground is essentially the antithesis among soil erosion preventative agents. Unfortunately, bare ground contributed a substantial percentage of the total plot area among all treatments among sampling periods (Table 9). Not surprising, the

*Means followed by the same letter within a sample date and probability level are not significantly different. 
Table 9. Mean bare ground at several sampling periods and significant differences at several levels of probability with wet and dry season treatments.

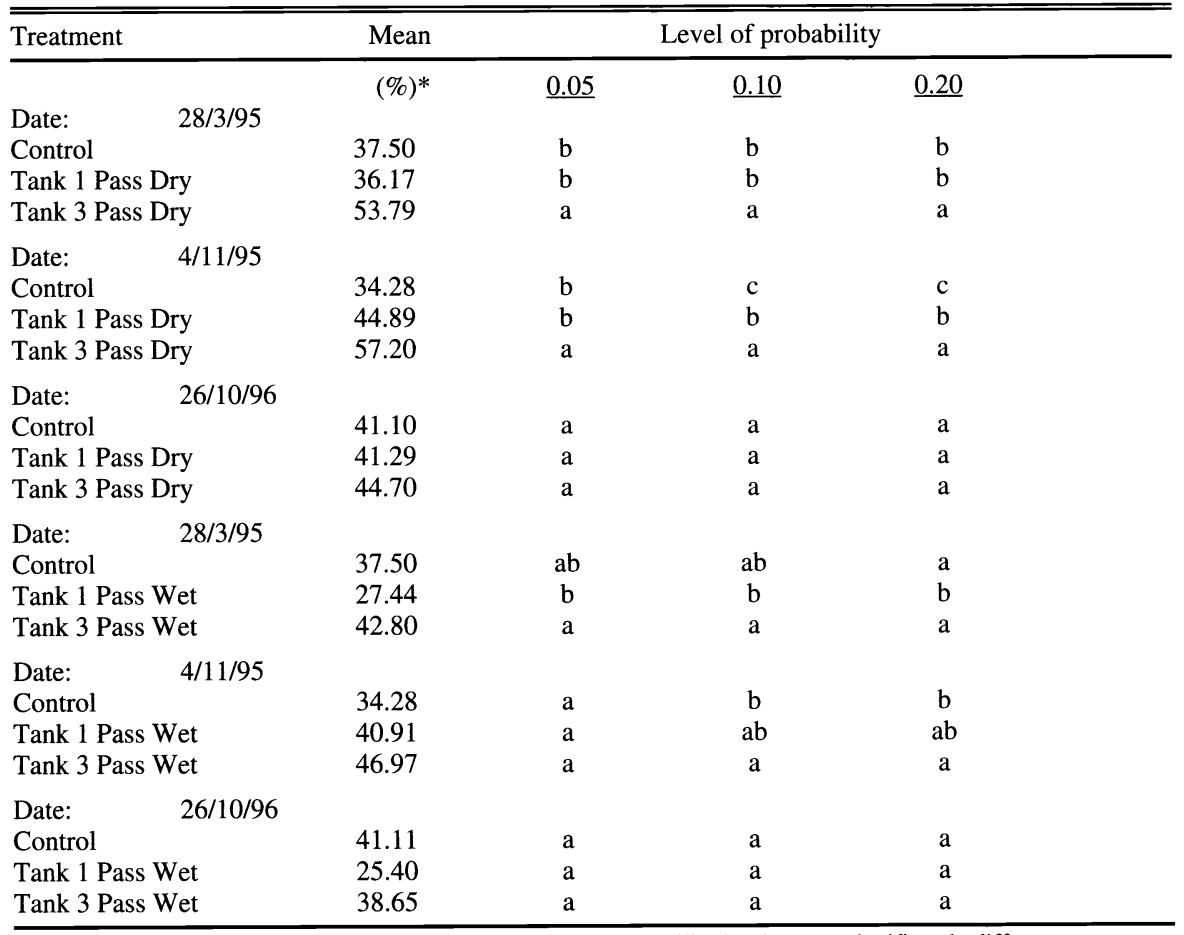

*Means followed by the same letter within a sample date and probability level are not significantly different. triple pass tank (dry) treatments maintained the highest mean bare ground percentages within each sampling period consecutively at 54,57 , and $45 \%$, and were significantly higher $(\mathrm{P}<0.20)$ on the 28 March 1995 and 4 November 1995 periods. Bare ground quite readily forms impermeable soil surface crusts on desert landscapes. These crusts are formed when wet soil aggregates are first broken down by raindrop impact and finer materials are washed into surface pores, reducing their volume. After aggregate destruction, raindrop impact causes compaction of the surface and produces a thin coating which is largely impermeable. The compaction is a function of the size and terminal velocity of raindrops. The surface sealing reduces infiltration rate, thus encouraging runoff. No significant differences among bare ground treatment (wet) means were found at the 0.05 level of probability between 4 November 1995 and 26 October 1996 sampling periods, and no differences $(0.20$ probability) were found among wet or dry season treatment means at the final, 26 October 1996 period.

\section{Surface Microtopography}

Surface roughness, microrelief, or microtopography is defined as a measure of variation in surface elevation (Huang and Bradford 1992). Surface microtopog- raphy is considered an important variable since greater surface undulations tend to increase hydraulic resistance, slow surface flow, and allow more time for infiltration This variable was reported as mean surface microtopographic variance (Table 10) among 4 plots per treatment and 2 repetitions between sampling periods (Kincaid and Williams 1966). Variance was calculated from 66 individual points measured with the point frame on each plot for each treatment and repetition. The control treatments, as expected, tended to have higher mean variance, though most results were quite variable. The general trend of most treatments was comparatively high mean variance on the first, 28 March 1995 sample period, and consecutively lower means through the final, October 1996 period. One possible explanation for this behavior is that the very intense precipitation events that occurred in the summer months prior to each of the last 2 sampling periods facilitated soil surface crusting. Such impermeable crusts would most likely exhibit more uniform surfaces because the intense rainfall events necessary to create the crusts would tend to break-apart and disperse surface soil aggregates, resulting in a smoother surface. Single pass tank (wet) treatment variance means were consistently lower than other treatments at all sampling periods. No difference was found at the 0.20 level of probability among all treatments for the dry season, (Eldridge 1991, Wood and Eldridge 1993).

Table 10. Mean surface microtopographic variance at several sampling periods and significant differences at several levels of probability with wet and dry season treatments.

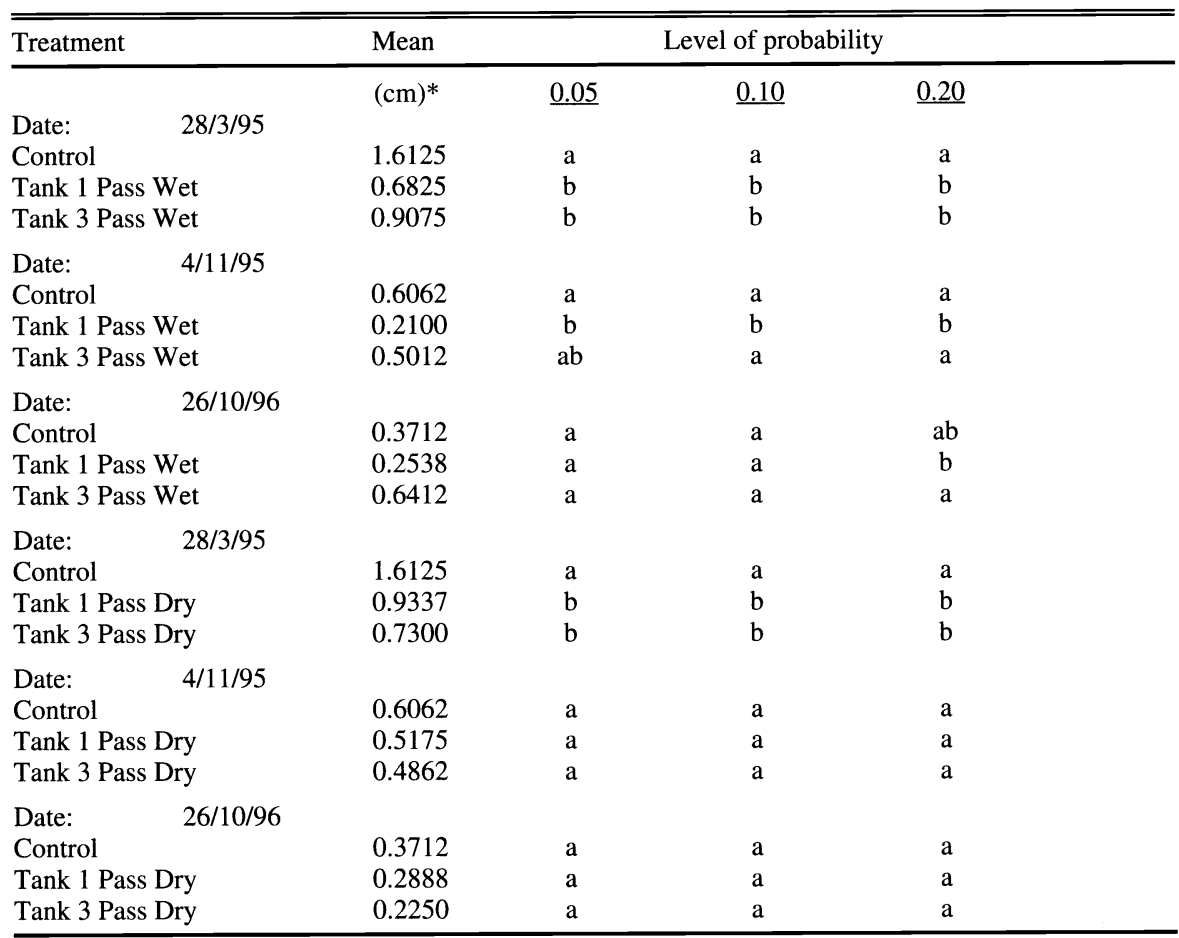

*Means followed by the same letter within a sample date and probability level are not significantly different. 
Table 11. Correlation analysis $(N=40)$ for wet season treatments for each surface property measured with cumulative sediment loss being the dependent variable.

\begin{tabular}{lrrl}
\hline \hline Independent variables & $\mathrm{R}^{*}$ & $\mathrm{~F}^{* *}$ & $\mathrm{P} * * *$ \\
\hline Grass cover & -0.34 & 5.12 & 0.029 \\
Forb cover & -0.02 & 0.01 & 0.912 \\
Shrub cover & -0.05 & 0.09 & 0.764 \\
Litter cover & -0.36 & 5.69 & 0.022 \\
Total plant cover & -0.52 & 14.32 & 0.001 \\
Rock cover & -0.23 & 2.04 & 0.161 \\
Bare cover & -0.36 & 5.70 & 0.022 \\
Microtopography & -0.48 & 1.58 & 0.022 \\
Grass cover + Litter cover & -0.53 & 7.35 & 0.022 \\
Grass cover + Litter cover + & & & \\
Microtopography & -0.62 & 7.45 & 0.001 \\
Bare ground + & & & \\
Microtopgraphy & -0.56 & 8.09 & 0.001 \\
Grass cover + Litter cover + & & & \\
Microtopography + Rock cover & -0.62 & 5.46 & 0.002 \\
\hline
\end{tabular}

*Multiple correlation coefficient $(\mathrm{R})$

** Variance ratio $(\mathrm{F})$

*** Level of probability $(\mathrm{P})$

on the second, 4 November 1995 and third, 26 October 1996 sampling periods.

\section{Correlation Analysis}

Cumulative sediment loss was identified as the dependent variable. Grass, forb, shrub, litter, total plant, rock, and bare ground cover, as well as microtopographic variance, were identified as independent variables.

Table 11 presents correlation coefficients for treatments under wet seasonal conditions. The most negatively and strongly correlated individual variable was total plant cover at $\mathrm{R}=-0.52, \mathrm{~F}=14.32$, at the 0.001 level of probability. As anticipated, higher values of total plant cover are associated with lower values of cumulative sediment loss. The most negatively and strongly correlated group of variables was grass cover, litter cover, and microtopographic variance. This combination pro-

duced an $\mathrm{R}=-0.62, \mathrm{~F}=7.45$, at the 0.001 level of probability.

Correlation coefficients were slightly lower for treatments under dry seasonal conditions (Table 12). Similar to wet season treatments' analysis, the most negatively and strongly correlated individual variable under dry conditions was total plant cover at $\mathrm{R}=-0.44, \mathrm{~F}=5.34$, at the 0.031 level of probability. The most negatively and strongly correlated group of variables was grass cover, litter cover, and rock cover at $\mathrm{R}=-0.48, \mathrm{~F}=2.68$, at the 0.14 level of probability.

\section{Conclusions}

The results from this study acknowledge the impact of military tracked vehicles in a desert rangeland environment. However,

Table 12. Correlation analysis $(N=40)$ for dry season treatments for each surface property measured with cumulative sediment loss being the dependent variable.

\begin{tabular}{lcll}
\hline \hline Independent variables & $\mathrm{R} *$ & $\mathrm{~F} * *$ & $\mathrm{P} * * *$ \\
\hline Grass cover & -0.33 & 2.74 & 0.112 \\
Forb cover & -0.04 & 0.04 & 0.837 \\
Shrub cover & 0 & 0 & 0 \\
Litter cover & -0.33 & 2.61 & 0.121 \\
Total plant cover & -0.44 & 5.34 & 0.031 \\
Rock cover & -0.38 & 3.74 & 0.066 \\
Bare cover & -0.17 & 0.68 & 0.417 \\
Microtopography & -0.1 & 0.22 & 0.644 \\
Grass cover + Litter cover & -0.45 & 2.68 & 0.092 \\
Grass cover + Litter cover + & & & \\
Rock Cover & -0.48 & 2.05 & 0.014 \\
Total plant + Rock cover & -0.47 & 3.3 & 0.07 \\
\hline *Multiple corrlation coefficient $(\mathrm{R})$ & & &
\end{tabular}

*Multiple correlation coefficient (R)

** Variance ratio $(\mathrm{F})$

*** Level of probability (P) the extent to which multiple pass disturbances are responsible for accelerated sediment loss in this study environment may not be altogether obvious, particularly where the effects of drought are concerned. Antecedent soil moisture conditions, as well as timing and intensity of precipitation, are widely recognized variables that play a profound role in governing the erosion process (Branson et al. 1981). To this end, it would not necessarily be correct to eliminate tracked vehicle training activities in the presence of drought, nor would it necessarily be correct in the presence of generally wet soil conditions. Rather, training activities should be scheduled with regard to landscape suitability and capacity to sustain disturbance, and should also be conducted with attention to site recovery. Individual installations may be able to implement site vehicle "carrying capacities," in which case these results should be helpful. Scheduling should reflect necessary recovery periods and sites should be monitored for progress. Although area soil surveys are an excellent source of information, reliance on soil loss tolerance estimates, "T-values" in particular, should be used with caution.

Despite the desire for stringent control of land management, it is very important to consider the inherent variability and unpredictable nature of climate and microclimate in rangeland systems. While some research is being conducted in this area (Ham et al. 1995, Polley et al. 1997), continued efforts are needed to better understand and describe the delineations between variable climate and land uses, and the associated impacts on the hydrologic cycle. The system variability creates the need for adaptive, proactive management. Such an approach endeavors to achieve environmental goals while maintaining the efficiency, longevity, and integrity of the land use operation in question. Watershed scale impacts need to be the subject of additional research.

\section{Literature Cited}

Abrahams, A.D., A.J. Perason, and S.H. Luk. 1988. Hydrologic and sediment responses to simulated rainfall on desert hillslopes in Southern Arizona. Catena 15:103-117.

Bonham, C.D. 1989. Measurements for terrestrial vegetation. John Wiley and Sons. New York, N.Y.

Branson, F.A., G.F. Gifford; K.G. Renard, and R.F. Hadley. 1981. Rangeland hydrology. Soci. for Range Manage.. Range Sci. Series No. 1. Kendall/Hunt Publishing Co. Dubuque, Iowa 
Braunack, M.V. 1986. The residual effects of tracked vehicles on soil surface properties. J. Terramechanics 23:37-50.

Brooks, K.N., P.F. Ffolliott, H.M. Gregersen, and J.L. Thames. 1991. Hydrology and the management of watersheds. Iowa State University Press. Ames, Iowa

Causton, D.R. 1988. An introduction to vegetation analysis; principles, practice and interpretation. Unwin Hyman Ltd. London, U.K.

Cooke, R., A. Warren, and A. Goudie. 1993. Desert geomorphology. UCL Press Limited, London, England.

Cook, C.W. and J. Stubbendieck. 1986. Range research: basic problems and techniques. Soc. Range Manage., Denver, Colo.

Derr, P.S. 1981. Soil survey of Otero area, New Mexico. Soil Conserv Serv., U.S. Dept. Agr., Washington, D.C.

Diersing, V. E. , J. A. Courson, S. D. Warren, D. J. Tazik, R. B. Shaw, and E. W. Novak. 1990. A climatic basis for planning military training operations and land maintenance activities. USA-CERL Tech. Rep. N-90/13. U. S. Army Corps of Eng., Champaign, Ill.

Douglas, I. 1967. Man, vegetation, and sediment yield of rivers. Nature 215:925-928.

Dunne, T. and L.B. Leopold. 1978. Water in environmental planning. W. H. Freeman and Company. San Francisco, Calif.

Eckert, R.E., M.K. Wood, W.H. Blackburn, and F.F. Peterson. 1979. Impact of off- road vehicles on infiltration and sediment production of two desert soils. J. Range Manage. 32:394-397.

Eldridge, D.J. 1991. An evaluation of cover type as a predictor of soil surface roughness in semiarid grassland. Aust. Rangel. J. 13:61-66.

Gardner, W.H. 1986. Water content. In Klute, A. (Ed.) Methods of soil analysis Part 1. Soil Sci. Soc. Amer. Madison, Wis.

Gifford, G.F. 1985. Cover allocation in rangeland watershed management (A review). pp 23-31. In: Jones, B. and T. Ward. (Eds.). Watershed Management in the eighties. Amer. Soc. Civil Eng., New York, N.Y.

Goran, W.D., L.L. Radke, and W.D. Servinghaus. 1983. An overview of the ecological effects of tracked vehicles on major $\mathrm{U}$. S. Army installations. USA-CERL Tech. Rep. N-142. U. S. Army Corps of Engineers, Champaign, Ill.

Hairsine, P.B. and C.W. Rose. 1992. Modeling water erosion due to overland flow using physical principles. I. Sheet flow. Water Resourc. Res. 28:237-243.

Ham, J.M., C.E. Owensby, P.I. Coyne, and D.J. Bremer. 1995. Fluxes of $\mathrm{CO}_{2}$ and water vapor from a prairie ecosystem exposed to ambient and elevated atmospheric $\mathrm{CO}_{2}$. Agr. For. Meteororol. 77:73-93.

Huang, C. and J.M. Bradford. 1992. Applications of a laser scanner to quantify soil microtopography. J. Soil Sci.. 56:14-21.

Johnson, D.A. and N.D. Gordon. 1988. Runoff and erosion from rainfall simulator plots on sagebrush rangeland. Trans. Amer. Soc. Agr. Eng. 31:421-427.

Johnson, F.L. 1982. Effects of tank training activities on botanical features at Fort Hood, Texas. Southwest Natur. 27:309-314.

Jury, W.A., W.R. Gardner, and W.H.
Gardner. 1991. Soil Physics. John Wiley \& Sons, New York, N.Y.

Kincaid, D.R. and G. Williams. 1966. Rainfall effects on soil surface characteristics following range improvement treatments. J. Range Mange. 19:346-351.

Langbein, W.B. and S.A. Schuum 1958. Yield of sediment in relation to mean annual precipitation. Ameri. Geo. Union, Trans. 39:1,076-1,084.

Lathrop, E.W. 1983. Recovery of perennial vegetation in military maneuver areas. p. 265-277. In: Webb, R.H. and H.G. Wilshire (eds) Environmental effects of off-road vehicles: impacts and management in arid regions. Springer-Verlag, New York, N.Y.

Lee, R. 1980. Forest hydrology. Columbia University Press. New York, N.Y

McCormack, D.E., K.K. Young, and L.W. Kimberlin. 1979. Current criteria for determining soil loss tolerance. In Determinants of Soil Loss Tolerance. Amer. Soc. Agron., Madison, Wis.

McKeys, E., E. Stemshorn, and R. Bousquet. 1980. Damage to agricultural fields by construction traffic. Trans. Amer. Soc. Agr. Eng. 23:1388-1391.

Moehring, D.M. and I.W. Rawls. 1970. Detrimental effects of wet weather logging. J Forest. 68:166-167.

Osborn, H.B. and K.G. Renard. 1969. Analysis of two runoff-producing southwest thunderstorms. J. Hydrol. 8: 282-302.

Parsons, A.J., A.D. Abrahams, and J. Wainwright. 1994. Rainsplash and erosion in an interrill area on semi-arid grassland, Southern Arizona. Catena 22:215-226.

Penman, H.L. 1948. Natural evaporation from open air, bare soil, and grass. Proc. Roy. Soc. A 190:120-145.

Polley, H.W., H.S. Mayeux, H.B. Johnson, and C.R. Tischler. 1997. Viewpoint: Atmospheric $\mathrm{CO}_{2}$, soil water and shrub/grass ratios on rangelands. J. Range Manage. 50:278-284.

Prose, D.V. and S.K. Metzger. 1985. Recovery of soils and vegetation in World War II military base camps, Mojave Desert. U.S. Geol. Surv. Open-File Rep. 85-234.

Prose, D.V., S.K. Metzger, and H.G. Wilshire. 1987. Effects of substrate disturbance on secondary plant succession; Mojave Desert, California. J. Appl. Ecol. 24:305-313.

Rogers, R.D. and S.A. Schumm. 1991. The effect of sparse vegetation cover on erosion and sediment yield. J. Hydrol. 123:19-24.

Sanchez, C.E. and M.K. Wood. 1987. The relationship of soil surface roughness with hydrologic variables on natural and reclaimed rangeland in New Mexico. J. Hydrol. 94:345-354.

Satterlund, D.R. and P.W. Adams. 1992. Wildland watershed management. $2^{\text {nd }}$ edition. John Wiley and Sons, Inc. New York, N.Y.

Severinghaus, W.D., R.E. Riggins, and W.D. Goran. 1979. Effects of tracked vehicle activity on terrestrial mammals, birds and vegetation at Fort Knox, Ky. USA-CERL Spec. Rep. N77. Champaign, Ill.

Shaw, R.B. and V.E. Diersing. 1990. Tracked vehicle impacts on vegetation at the Pinon Canyon Maneuver Site, Colorado. J. Environ. Qual. 19:234-243.

Smith, L.C. and G.A. Olyphant. 1994. Within- storm variations in runoff and sediment export from rapidly eroding coal-refuse deposit. Earth Surf. Process. Landforms 19:369-375.

Thompson, A.L. and L.G. James. 1985. Water droplet impact and its effects on infiltration. Trans. Amer. Soc. Agr. Eng. 28:1282-1285.

Thurow, T.L. 1991. Hydrology and erosion. Pp. 141-159. In: Heitschmidt, R. K. and J. W. Stuth. (Eds.). Grazing management an ecological perspective. Timber Press. Portland, Ore.

Tricker, A.S. 1981. Spatial and temporal patterns of infiltration. J. Hydrol. 49:261-277.

Vallentine, J.F. 1974. Range development and improvements. Brigham Young Univ. Press, Provo, Ut.

Van Doren, D.M. Jr. 1959. Soil compaction studied to determine effect on plant growth. Ohio Farm and Home Res. 44:2.04-2.05.

Warren, S.D., V.E. Diersing, P.J. Thompson, and W.D. Goran. 1991. An erosion-based land classification system for military installations. USA-CERL Tech. Manu. N-91/05. Champaign, Ill.

Webb, R.H., H.G. Wilshire, and M.A. Henry. 1983. Natural recovery of soils and vegetation following human disturbance. P279-302. In: Webb, R.H. and H.G. Wilshire (eds). Environmental effects of off-road vehicles: impacts and management in arid regions. Springer-Verlag, New York, N.Y.

Wight, J.R. and F.H. Siddoway. 1981. Determinants of soil loss tolerance for rangelands. In: B. L. Schmidt (ed.). Determinants of soil loss tolerance. Special publication, Amer. Soc. Agron., Madison, Wis.

Wilcox, B.P. and M.K. Wood. 1986. Factors influencing infiltration and erosion in the Guadalupe Mountains of New Mexico. pp. II I- 122. In: Morel-Seytoux, H. J. and J. W. Warner. (eds.). Proc. AGU Front Range Branch Hydrology Days No. 6.

Wilshire, H. 1991. Recovery of arid lands used for armored maneuvers and ancillary developments. Proc. Dept. of Defense Natural Resource Leadership Conf. Aug 12-16, Colorado Springs, Colo.

Wischmeier, W.H. and D.D. Smith. 1978. Predicting rainfall erosion losses-a guide to conservation planning. USDA Agr. Handb. 537. U.S. Gov. Print. Office. Washington, D.C.

Wood, M.K. 1988. Rangeland vegetation-hydrologic interactions. pp. 469-491. In: Tuller, P. T. (Ed.). Vegetation science applications for rangeland analysis and management. Kluwer Academic Publishers. Boston, Mass.

Wood, M.K. and D. Eldridge. 1993. Ode to Green and Ampt's f. Rangelands 15:228-232.

Wood, M.K. T.L. Jones, and M.T. Vera-Cruz. 1998. Rainfall interception by selected plants in the Chihuahuan Desert. J. Range Manage. 51:91-96.

Wood, M.K., D. Hereford, C. Souders, and A. Hill. 1994. Variations in plants, soils, water, and erosion in a pinyon pine (Pinus edulis Engelm.) - juniper (Juniperus deppeana Steud.) dominated range site. In: Blackburn, W.H., F.B. Pierson, Jr., G.E. Schuman, and R. Zartman (Eds.). Variability in Rangeland Water Erosion Processes. Soil Sci. Soc. Amer. Special Publication No. 38. pp. 93-106. 